\title{
The effect of relocation of whole-crop wheat and corn silages on their quality
}

\author{
Y. Chen and Z. G. Weinberg ${ }^{1}$ \\ Forage Preservation and By-Products Research Unit, Department of Food Quality and Safety, The Volcani Center, Bet Dagan 50250, Israel
}

\begin{abstract}
Whole-crop wheat and corn silages in 1.5-L anaerobic jars were exposed to air for 0 up to $48 \mathrm{~h}$ during their anaerobic storage period to simulate relocation of silages. Ensiling treatments included control (no additives) and either Koffosil T (Koffolk Inc., Petah Tikva, Israel) comprising a mixture of organic acids or Lactobacillus plantarum MTD1 (Ecosyl Products Ltd., Stokesley, UK). In the first set of experiments, the duration of exposure to air had little effect on ensiling parameters or on the aerobic stability of the final silages. In the second set of experiments, both the inoculant and duration of exposure to air had an effect on various fermentation parameters and on the aerobic stability of the final silages. We concluded that if the silages are of good quality, the duration of the relocation process has little effect on silage quality or its aerobic stability. However, if the silage contains any factor that may affect its aerobic stability, it is more sensitive to the time it takes to re-ensile the forage.
\end{abstract}

Key words: relocation, silage quality, aerobic stability

\section{INTRODUCTION}

Silage making is based on anaerobic fermentation, whereby lactic acid bacteria convert water-soluble carbohydrates into organic acids, mainly lactic acid. As a result, the $\mathrm{pH}$ decreases and the forage is preserved. Air is detrimental to the ensiling process, as it enables aerobic microorganisms to proliferate and spoil the silage (Woolford, 1990). Therefore, it is important to prevent air ingress into the silage by compaction of the crop particles during silage making and sealing it properly. However, some air usually penetrates into the silage during storage and feedout from the top and the unloading face (Ashbell and Weinberg, 1992; Weinberg and Ashbell, 1994).

In Israel, it sometimes is necessary to relocate commercial silages stored in bunker silos. This happens for various reasons related to current Israeli dairy cattle management. Smaller individual farms may merge into

Received June 4, 2013.

Accepted July 18, 2013.

${ }^{1}$ Corresponding author: zgw@volcani.agri.gov.il larger ones, and silages that were prepared on one farm are moved to the new location. Sometimes, empty bunker silos on small farms are filled by silage contractors who ship them as needed, mainly from the relatively rainy northern part of Israel to the arid south. In another situation, crop surplus may be ensiled in remote silos during the harvesting season and later moved to a bunker that is closer to the dairy farm.

Relocation of commercial silage involves unloading, transportation, recompaction, and sealing in the new silo. Such operations might take from several hours to 1 or $2 \mathrm{~d}$, during which time the silage is inevitably exposed to air. In such circumstances, it is often asked how much damage is incurred by the relocation of the silage. The objective of the current experiments was to measure losses and changes in silages during relocation in model systems.

\section{MATERIALS AND METHODS}

\section{Experiments}

The experiments were performed in 2011 and 2012. In 2011, wheat at the flowering and milk stages of maturity and corn at the half milk dent stage were ensiled in 1.5-L anaerobic jars (J. Weck $\mathrm{GmbH}$ und Co. KG, Wehr-Öflingen, Germany). Silage treatments included control (no additives) and Koffosil T (Koffolk Inc., Petah Tikva, Israel), a chemical additive comprising organic acids, applied at $0.5 \mathrm{~g} / \mathrm{kg}$. The wheat and corn silages were stored at room temperature $\left(25 \pm 2^{\circ} \mathrm{C}\right)$ for 5 and 2 mo, respectively. Then, they were emptied into open plastic tubs and re-ensiled after 4 to 6,16 to 17,24 to 26 , and 48 to $50 \mathrm{~h}$. There were 3 jars per exposure time, and 3 jars were kept sealed until the end of the experiment. Similar experiments were performed in 2012 with wheat from the milk stage and corn; silage treatments included control and addition of Lactobacillus plantarum MTD1 (Ecosyl Products Ltd., Stokesley, UK) applied at $10^{6} \mathrm{cfu} / \mathrm{g}$, and the exposure times in the tubs were $4,8,24$, and $48 \mathrm{~h}$.

The weight of the jars was determined immediately after the first sealing, just before the first opening, immediately after the second sealing, and at the end of the experiments. The re-ensiled jars were stored for an additional $1.5 \mathrm{mo}$, after which they were subjected to an 
aerobic stability test in bottle systems for $5 \mathrm{~d}$ at $30^{\circ} \mathrm{C}$. The aerobic stability test was conducted in triplicate using recycled 1.5-L polyethylene-terephthalate (soft drink) bottles. These systems consisted of 2 parts: the upper part included the screw cork with holes bored in the cork and in the lid of the opposite side. This part was filled with ca. $250 \mathrm{~g}$ of silage and was placed upside down over a fitting beaker that contained $100 \mathrm{~mL}$ of $20 \% \mathrm{KOH}$. In these systems, change in $\mathrm{pH}$, production of $\mathrm{CO}_{2}$, and numbers of yeasts and molds, as well as visual appearance, served as spoilage indicators. The $\mathrm{CO}_{2}$ that was absorbed in the base solution was determined on $10-\mathrm{mL}$ aliquots diluted with $90 \mathrm{~mL}$ of water, by titration with $1 \mathrm{~N} \mathrm{HCl}$ between $\mathrm{pH} 8.1$ and 3.6, according to the $\mathrm{pK}$ values $\left[\log _{10}\left(1 / \mathrm{K}_{\mathrm{a}}\right)\right.$, where $\mathrm{K}_{\mathrm{a}}$ is the acid dissociation constant] of carbonic acid (Ashbell et al., 1991; Weinberg et al., 2009).

\section{Analyses}

Dry matter content was determined in triplicate by oven drying for $48 \mathrm{~h}$ at $60^{\circ} \mathrm{C}$. Dry matter losses were calculated from weight losses and differences in DM content. Ash content was obtained in a muffle oven after $3 \mathrm{~h}$ at $550^{\circ} \mathrm{C}$. Lactic acid concentration was determined by the spectrophotometric method of Barker and Summerson (1941). Ethanol and VFA concentrations were determined in aqueous extracts with a gas chromatograph equipped with a semi capillary FFAP (nitroterephthalic acid-modified polyethylene glycol) column (Hewlett-Packard, Waldbronn, Germany), over a temperature range of 40 to $230^{\circ} \mathrm{C}$. Neutral detergent fiber [NDF inclusive of ash - NDF] concentration was determined according to Van Soest et al. (1991) with an Ankom fiber analyzer (Ankom Technology, Macedon, NY). Losses in the mini-silos were assessed by weighing. The DM and NDF digestibility were determined with the 2-stage fermentation technique according to Tilley and Terry (1963), with all samples in triplicate. Rumen fluid was obtained from a ruminally fistulated dry Holstein cow fed $6 \mathrm{~kg}$ (as DM) of wheat hay and $4 \mathrm{~kg}$ (as DM) of TMR containing 30\% of concentrated grains, $35 \%$ of wheat and corn silages, $15 \%$ of soybean and sunflower meals, and $20 \%$ by-products (cottonseed, wheat bran, and gluten feed). Microbiological evaluation included enumeration of yeasts and molds on spread-plate malt extract agar (Difco Laboratories Inc., Detroit, MI) acidified to $\mathrm{pH} 4.0$ with lactic acid. The plates were incubated for $3 \mathrm{~d}$ at $30^{\circ} \mathrm{C}$. Microbiological analysis was performed on a single representative silage sample from each treatment.

\section{Statistical Analysis}

Statistical analysis included ANOVA and the Tukey studentized range test, which were performed with
PROC GLM procedure of SAS (SAS Institute Inc., Cary, NC). The main effects included silage treatments, re-location duration, and their interactions.

\section{RESULTS}

The experiments with the wheat and corn silages from 2011 revealed that exposing the silages for up to $48 \mathrm{~h}$ resulted in only some drying of the forage. However, DM losses, aerobic stability, and other silage parameters were not affected significantly $(P<0.05)$ by the exposure to air. Table 1 summarizes the results from the experiment with the corn silages as an example for this set of experiments. In the aerobic stability test, the $\mathrm{pH}$ values remained at $4.2, \mathrm{CO}_{2}$ production was low $(1.0-2.2 \mathrm{~g} / \mathrm{kg}$ of $\mathrm{DM})$, and yeast and mold numbers were below the detection limit $\left(\log _{10} \mathrm{cfu} / \mathrm{g}<2\right)$. The longer exposure times resulted in a significant decrease in DM and amylase-treated NDF digestibility.

Results from the experiment with the wheat silage from 2012 are presented in Table 2. Time of exposure did not affect DM losses; however, ensiling losses decreased significantly by the added lactic acid bacteria inoculants. Both the control and inoculated silages had relatively high ethanol concentrations. The various control silages had higher contents of acetic and butyric acids (10-14 and 19-24 g/ kg of DM, respectively) than the inoculated silages (6-8 and 3-12 $\mathrm{g} / \mathrm{kg}$ of DM, respectively), whereas lactic acid content was higher in the inoculated silages (59-64 vs. $25-43 \mathrm{~g} / \mathrm{kg}$ of DM in the inoculated and control silages, respectively, with a significant treatment effect). The duration of exposure to air of the silages in the middle of the anaerobic storage resulted in substantial drying of the silages and affected ethanol and butyric acid contents and DM digestibility but not lactic and acetic acid contents.

Results from the experiment with the corn silage from 2012 are presented in Table 3. The lactic acid bacteria inoculant had an effect on fermentation end products and resulted in decreased losses. The acetic acid content of the control and inoculated silages was 8 to 15 and 4 to $9 \mathrm{~g} / \mathrm{kg}$ of DM, respectively. The duration of exposure to air of the silages in the middle of the anaerobic storage resulted in a decrease in fermentation product concentrations but it did not affect total DM ensiling losses or ash or digestibility values.

Table 4 summarizes the aerobic stability test of the wheat and corn silages from 2012, which was performed after the final opening of the jars. Values for each treatment are given separately because the experiments were designed so that the inoculants should affect the aerobic stability of the silages as compared with the control silages. In the wheat silages, treatment with $L b$. plantarum had a significant effect on 


\begin{tabular}{|c|c|c|c|c|c|c|c|c|c|c|c|c|c|}
\hline \multirow[b]{2}{*}{ tem } & \multirow[b]{2}{*}{$\begin{array}{c}\mathrm{DM} \\
(\mathrm{g} / \mathrm{kg})\end{array}$} & \multirow[b]{2}{*}{$\begin{array}{l}\text { Total DM } \\
\text { loss }(\%)\end{array}$} & \multirow[b]{2}{*}{$\mathrm{pH}$} & \multirow[b]{2}{*}{$\begin{array}{l}\text { Lactic } \\
\text { acid }\end{array}$} & \multirow[b]{2}{*}{ Ethanol } & \multirow[b]{2}{*}{$\begin{array}{l}\text { Acetic } \\
\text { acid }\end{array}$} & \multirow[b]{2}{*}{$\begin{array}{l}\text { Propionic } \\
\text { acid }\end{array}$} & \multirow[b]{2}{*}{ Ash } & \multirow[b]{2}{*}{$\mathrm{NDF}^{2}$} & \multirow[b]{2}{*}{$\begin{array}{c}\mathrm{DM} \\
\text { digestibility }\end{array}$} & \multirow[b]{2}{*}{$\begin{array}{c}\mathrm{NDF}^{2} \\
\text { digestibility }\end{array}$} & \multicolumn{2}{|c|}{$\begin{array}{l}\text { After the aerobic } \\
\text { stability test }\end{array}$} \\
\hline & & & & & & & & & & & & $\begin{array}{c}\mathrm{Co}_{2} \\
(\mathrm{~g} / \mathrm{kg} \text { of } \mathrm{DM})\end{array}$ & $\mathrm{pH}$ \\
\hline $\begin{array}{l}\text { Fresh corn } \\
\text { Be-ensiling duration (b) }\end{array}$ & 381 & - & 5.4 & - & - & - & - & 49 & 513 & 675 & 511 & & \\
\hline 0 & $355^{\mathrm{b}}$ & 8.8 & 4.2 & 27 & $6^{\mathrm{a}}$ & 30 & 4 & 51 & 474 & $719^{\mathrm{a}}$ & $492^{\mathrm{a}}$ & 1.8 & 4.2 \\
\hline 6 & $358^{\mathrm{b}}$ & 8.4 & 4.1 & 23 & $2^{\mathrm{b}}$ & 27 & 4 & 53 & 496 & $706^{\mathrm{a}}$ & $508^{\mathrm{a}}$ & 2.2 & 4.2 \\
\hline 16 & $368^{\mathrm{ab}}$ & 9.4 & 4.2 & 18 & $1^{\mathrm{b}}$ & 25 & 3 & 52 & 479 & $715^{\mathrm{a}}$ & $496^{\mathrm{a}}$ & 1.0 & 4.2 \\
\hline 24 & $363^{\mathrm{b}}$ & 8.9 & 4.2 & 27 & $1^{\mathrm{b}}$ & 28 & 4 & 54 & 502 & $682^{\mathrm{ab}}$ & $454^{\mathrm{ab}}$ & 2.1 & 4.2 \\
\hline 48 & $389^{\mathrm{a}}$ & 7.5 & 4.2 & 22 & $2^{\mathrm{b}}$ & 24 & 3 & 49 & 453 & $658^{\mathrm{b}}$ & $401^{\mathrm{a}}$ & 2.2 & 4.2 \\
\hline SEM & 11.1 & 2.67 & 0.07 & 5.2 & 1.3 & 4.3 & 0.7 & 3.0 & 28.8 & 21.6 & 30.3 & 0.73 & 0.06 \\
\hline ffect & & & & & & & & & & & & & \\
\hline Treatment $(\mathrm{T})$ & 0.057 & $\mathrm{NS}^{3}$ & NS & NS & 0.043 & NS & NS & $\mathrm{NS}$ & NS & 0.002 & 0.002 & 0.087 & NS \\
\hline Duration (D) & 0.001 & NS & NS & NS & $<0.0001$ & 0.091 & NS & NS & 0.088 & 0.003 & 0.001 & NS & NS \\
\hline $\mathrm{T} \times \mathrm{D}$ & NS & NS & NS & NS & NS & 0.052 & NS & NS & 0.047 & 0.002 & 0.002 & NS & NS \\
\hline
\end{tabular}

${ }^{\mathrm{a}, \mathrm{b}}$ Means within a column followed by different superscripts differ significantly $(P<0.05)$.

${ }^{1}$ Treatment comprised a chemical additive of organic acids (Koffosil T; Koffolk Inc., Petah Tikva, Israel). Yeast and mold numbers in the fresh corn were both log $10=6.8 / \mathrm{g}$ of DM. No yeasts or molds were detected in any of the silages after the second opening or after the aerobic stability test when all samples were clean.

${ }^{2}$ Neutral detergent fiber inclusive of ash.

${ }^{3} \mathrm{NS}=$ nonsignificant at $P>0.10$.

Table 2. Chemical analysis of the final wheat silages $(\mathrm{g} / \mathrm{kg} \text { of DM; } 2012)^{1}$

\begin{tabular}{|c|c|c|c|c|c|c|c|c|c|c|c|}
\hline Item & $\begin{array}{c}\mathrm{DM} \\
(\mathrm{g} / \mathrm{kg})\end{array}$ & $\begin{array}{c}\text { Total DM } \\
\text { loss (\%) }\end{array}$ & $\mathrm{pH}$ & $\begin{array}{l}\text { Lactic } \\
\text { acid }\end{array}$ & Ethanol & $\begin{array}{l}\text { Acetic } \\
\text { acid }\end{array}$ & $\begin{array}{l}\text { Butyric } \\
\text { acid }\end{array}$ & Ash & $\mathrm{NDF}^{2}$ & $\begin{array}{c}\mathrm{DM} \\
\text { digestibility }\end{array}$ & $\begin{array}{c}\mathrm{NDF}^{2} \\
\text { digestibility }\end{array}$ \\
\hline Fresh wheat & 301 & - & 6.0 & - & - & - & - & 79 & 634 & 575 & 623 \\
\hline \multicolumn{12}{|l|}{$\begin{array}{l}\text { Re-ensiling duration } \\
\text { (h) }\end{array}$} \\
\hline 0 & $282^{\mathrm{c}}$ & 7.9 & 4.2 & 49 & $18^{\mathrm{a}}$ & 9 & $18^{\mathrm{a}}$ & 96 & 667 & $546^{\mathrm{a}}$ & 604 \\
\hline 4 & $295^{\mathrm{c}}$ & 8.1 & 4.1 & 53 & $20^{\mathrm{a}}$ & 11 & $13^{\mathrm{ab}}$ & 96 & 674 & $534^{\mathrm{ab}}$ & 608 \\
\hline 8 & $314^{\mathrm{b}}$ & 7.3 & 4.1 & 49 & $13^{\mathrm{ab}}$ & 10 & $12^{\mathrm{ab}}$ & 99 & 670 & $543^{\mathrm{a}}$ & 615 \\
\hline 24 & $327^{\mathrm{b}}$ & 10.4 & 4.2 & 44 & $12^{\mathrm{ab}}$ & 10 & $15^{\mathrm{ab}}$ & 98 & 679 & $512^{\mathrm{b}}$ & 590 \\
\hline 48 & $368^{\mathrm{a}}$ & 9.0 & 4.1 & 45 & $7^{\mathrm{b}}$ & 9 & $11^{\mathrm{b}}$ & 96 & 675 & $530^{\mathrm{ab}}$ & 601 \\
\hline SEM & 8.2 & 2.80 & 0.13 & 5.4 & 5.7 & 2.2 & 3.5 & 4.9 & 9.4 & 16.8 & 27.8 \\
\hline \multicolumn{12}{|l|}{ Effect } \\
\hline Treatment $(\mathrm{T})$ & 0.0029 & 0.0004 & $<0.0001$ & $<0.0001$ & 0.0042 & $<0.0001$ & $<0.0001$ & 0.0012 & $\mathrm{NS}^{3}$ & 0.0013 & NS \\
\hline Duration (D) & $<0.0001$ & NS & NS & 0.090 & 0.0077 & NS & 0.025 & NS & NS & 0.017 & NS \\
\hline $\mathrm{T} \times \mathrm{D}$ & NS & NS & NS & 0.071 & 0.047 & NS & NS & NS & NS & NS & NS \\
\hline
\end{tabular}

${ }^{\mathrm{a}-\mathrm{c} M e a n s}$ within a column followed by different superscripts differ significantly $(P<0.05)$.

${ }^{1}$ Treatment comprised silage inoculant Lactobacillus plantarum MTD1 (Ecosyl Products Ltd., Stokesley, UK). Yeasts were below the detection level (log 10 cfu $<2 / \mathrm{g}$ of DM) in all control silages after the second opening, and in low numbers (up to $\log _{10} \mathrm{cfu}=3.0 / \mathrm{g}$ of DM) in the inoculated silages. No molds were detected in any of the wheat silages after the second opening. Propionic acid was detected in negligible concentrations in a few samples only.

${ }^{2}$ Neutral detergent fiber inclusive of ash.

${ }^{3} \mathrm{NS}=$ nonsignificant at $P>0.10$. 
Table 3. Chemical analysis of the final corn silages (g/kg of DM; 2012) ${ }^{1}$

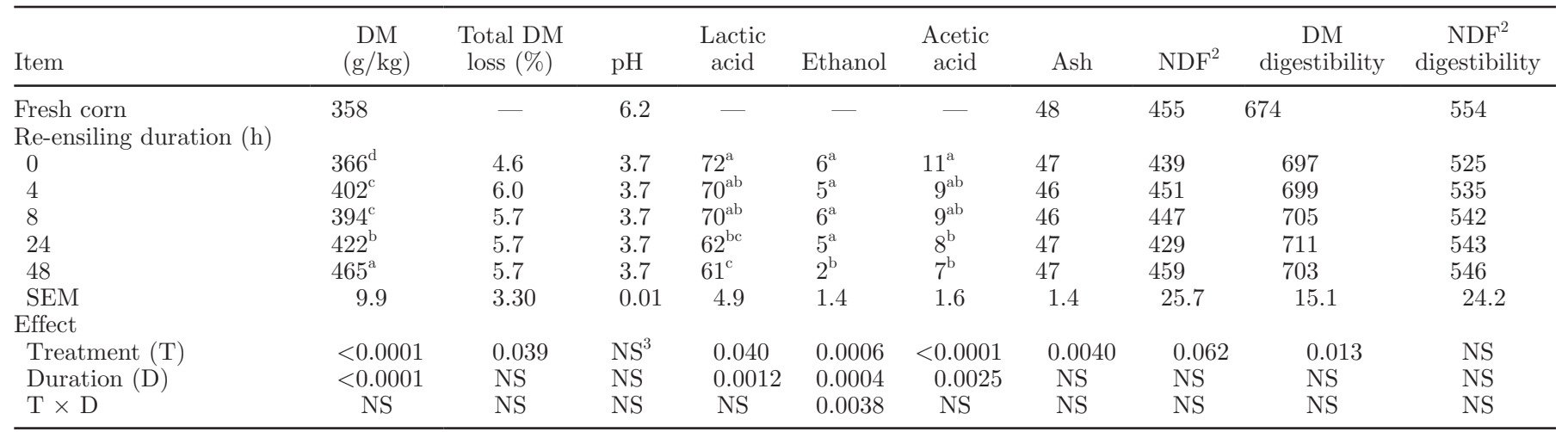

${ }^{\mathrm{a}-\mathrm{d}}$ Means within a column followed by different superscripts differ significantly $(P<0.05)$.

${ }^{1}$ Treatment comprised silage inoculant Lactobacillus plantarum MTD1 (Ecosyl Products Ltd., Stokesley, UK). After the second opening, no yeasts or molds were found in the control silages, which were sealed throughout the experiment; the other control and inoculated silages contained yeasts up to $\log _{10} \mathrm{cfu}=4.8 / \mathrm{g}$ of DM. Molds were detected only in the control silages ( up to $\log _{10} \mathrm{cfu}=4.0 / \mathrm{g}$ of DM). Propionic acid was detected in negligible concentrations in a few samples only.

${ }^{2}$ Neutral detergent fiber inclusive of ash.

${ }^{3} \mathrm{NS}=$ nonsignificant at $P>0.10$.

$\mathrm{CO}_{2}$ production and resulted in more intensive aerobic deterioration compared with the control silages. In the corn silages, both the control and inoculated silages spoiled upon aerobic exposure, except for the control silage, which remained sealed throughout the experiment and was stable in the final aerobic stability test. The duration of exposure to air in the middle of the anaerobic storage had a marginally significant effect $(P=0.072)$ on $\mathrm{CO}_{2}$ production, whereas the inoculant significantly affected the $\mathrm{pH}$ changes during the final aerobic stability test.

\section{DISCUSSION}

Whether to move silage from one silo to another is a question that is often asked by farmers and producers. During such operation, the silage is inevitably exposed to air, enabling aerobic spoiling microorganisms to proliferate. In corn and small-grain whole-crop silages, aerobic yeasts and molds are the major spoiling microorganisms during exposure of the silage to air (Pahlow et al., 2003). Mahana and Chase (2003) hypothesized that the success or failure of silage moving depends very

Table 4. Results of the aerobic stability test of the final wheat and corn silages $\left(2012 ; \text { yeast and } \operatorname{mold}_{\text {numbers }} \text { are given as } \log _{10} \text { cfu/g of } \mathrm{DM}\right)^{1}$

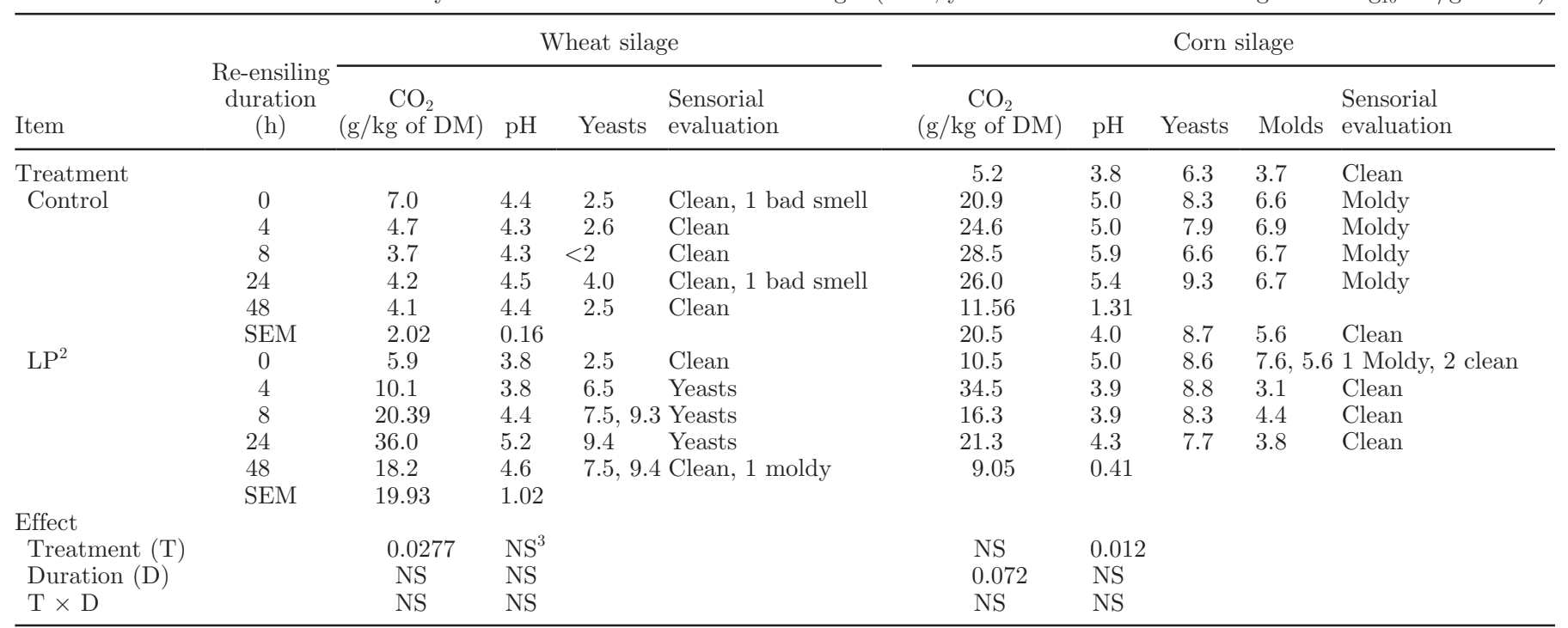

${ }^{1}$ No molds were detected in any of the wheat silages after the aerobic stability test.

${ }^{2}$ Lactobacillus plantarum MTD1 (Ecosyl Products Ltd., Stokesley, UK).

${ }^{3} \mathrm{NS}=$ nonsignificant at $P>0.10$. 
much on its condition; well-ensiled and stored silage can be moved successfully, if the relocation operation is quick and the unloading rate is fast. In the current experiments, laboratory silages that were exposed to air for different lengths of time in the middle of their anaerobic storage period were used as a model for moving silages. Our hypothesis was that the longer the time the silages were exposed to air during re-ensiling, the larger the spoilage and more intensive the aerobic deterioration would be. Therefore, in the experiments of 2011, we included an additive comprising organic acids that would protect the silage upon aerobic exposure. Quite surprisingly, both the control and treated silages were not affected markedly by the exposure to air, up to $48 \mathrm{~h}$ (Table 1). Therefore, in the next set of experiments (2012) we used a homofermentative lactic acid bacteria inoculant comprising $L b$. plantarum to induce aerobic deterioration at least in the silages of 1 treatment. Such inoculants enhance aerobic deterioration because they do not produce enough VFA in the silage, which inhibit yeasts and molds (Weinberg et al., 1993). Overall, the control wheat silages had higher acetic and butyric acid concentrations than the inoculated wheat silages, and the control corn silages had higher acetic acid concentration than the inoculated corn silages. Indeed, the inoculated wheat silages of 2012 spoiled in the final aerobic stability test, whereas all the control and inoculated corn silages deteriorated, except for the control corn silage, which was kept sealed throughout the experiment (Table 4). Duration of exposure to air in the middle of the storage period of the corn silages had only a marginal effect on $\mathrm{CO}_{2}$ production during the final aerobic stability test. The large standard errors of the mean reflect inconsistency among triplicate samples, which is also evident from the sensorial evaluation.

Overall, our results agree with the hypothesis of Mahana and Chase (2003) that the success of silage relocation depends on its fermentation profile, yeast and mold load, and to a lesser extent, on the speed of relocation. Low $\mathrm{pH}$ values are not enough to protect the silage while moving; it should contain high enough levels of VFA to prevent aerobic deterioration in the new silo. For practical purposes, we would suggest to determine fermentation products and yeast and mold counts before deciding to move silage.

\section{CONCLUSIONS}

Whole-crop wheat and corn silages of good quality with enough VFA should be safe to move. For highquality silages, the time it takes to relocate is not crucial. However, if yeast and mold counts are high, or if treated with a homofermentative lactic acid bacteria, it is much more susceptible to aerobic exposure and the chance of suffering high losses during later feeding is higher.

\section{ACKNOWLEDGMENTS}

Contribution from the Agricultural Research Organization, The Volcani Center (Bet Dagan, Israel) No. 657/13-E 2013 Series is acknowledged. This research was funded by the Israeli Milk Board (Caesarea Industrial Park, Israel).

\section{REFERENCES}

Ashbell, G., and Z. G. Weinberg. 1992. Top silage losses in horizontal silos. Can. Agric. Eng. 34:171-175.

Ashbell, G., Z. G. Weinberg, A. Azrieli, Y. Hen, and B. Horev. 1991. A simple system to study the aerobic deterioration of silages. Can. Agric. Eng. 33:391-394.

Barker, B., and W. H. Summerson. 1941. The colorimetric determination of lactic acid in biological material. J. Biol. Chem. 138:535554.

Mahana, B., and L. Chase. 2003. Chapter 19: Practical applications and solutions to silage problems. Pages 855-895 in Silage Science and Technology. Agronomy Monograph 42. D. R. Buxton, R. E. Muck, and J. H. Harrison, ed. American Society of Agronomy, Madison, WI.

Pahlow, G., R. E. Muck, F. Driehuis, S. J. W. H. Oude Elferink, and S. F. Spoelstra. 2003. Chapter 2: Microbiology. Pages 31-93 in Silage Science and Technology. Agronomy Monograph 42. D. R. Buxton, R. E. Muck, and J. H. Harrison, ed. American Society of Agronomy, Madison, WI.

Tilley, J. M. A., and R. A. Terry. 1963. A two-stage technique for the in vitro digestion of forage crops. J. Br. Grassl. Soc. 18:104-111.

Van Soest, P. J., J. B. Robertson, and B. A. Lewis. 1991. Methods for dietary fiber, neutral detergent fiber, and nonstarch polysaccharides in relation to animal nutrition. J. Dairy Sci. 74:3583-3597.

Weinberg, Z. G., and G. Ashbell. 1994. Changes in gas composition in corn silages in bunker silos during storage and feedout. Can. Agric. Eng. 36:155-158.

Weinberg, Z. G., G. Ashbell, Y. Hen, and A. Azrieli. 1993. The effect of applying lactic acid bacteria at ensiling on the aerobic stability of silages. J. Appl. Bacteriol. 75:512-518.

Weinberg, Z. G., Y. Chen, and R. Solomon. 2009. The quality of commercial wheat silages in Israel. J. Dairy Sci. 92:638-644.

Woolford, M. K. 1990. The detrimental effects of air on silage. J. Appl. Bacteriol. 68:101-116. 